\title{
Free radical studies of components of the extracellular matrix: contributions to protection of biomolecules and biomaterials from sterilising doses of ionising radiation
}

\author{
Barry J. Parsons
}

Received: 28 June 2017/Accepted: 8 August 2017/Published online: 4 September 2017

(C) The Author(s) 2017. This article is an open access publication

\begin{abstract}
The purpose of the current review is show how the principles and techniques of radiation chemistry have enabled the direct reactions of free radicals with biomolecules and biomaterials to be investigated at the molecular level. In particular, the review focusses on the free radical-induced fragmentation of glycosaminoglycans. Glycosaminoglycans are large linear polysaccharides consisting of repeating disaccharide units and are important components of the extracellular matrix (ECM) either in free form (hyaluronan) or as a component of proteoglycans. Oxidative damage of the extracellular matrix components by either enzymatic or non-enzymatic pathways may have implications for the initiation and progression of a range of human diseases. These include arthritis, kidney disease, cardiovascular disease, lung disease, periodontal disease and chronic inflammation. Oxidative damage to hyaluronan by reactive oxidative species and thus the potential mechanism of damage to the ECM and its role in human pathologies is reviewed with particular focus on damage initiated by potential in vivo free radicals such as superoxide, carbonate and hydroxyl radicals. Such knowledge has also allowed radiation protecting systems to be developed so that sterilising doses of radiation can be delivered to sensitive biomolecules such as proteins and
\end{abstract}

B. J. Parsons ( $\square)$

School of Clinical and Applied Sciences, Leeds Beckett

University, Leeds LS1 3HE, UK

e-mail: b.parsons@leedsbeckett.ac.uk glycosaminoglycans, and also to sensitive biomaterials such as tissue allografts.

Keywords Hyaluronan - Free radicals . Inflammation · Tissue allografts $\cdot$ Sterilisation

\section{Introduction}

Glycosaminoglycans are large linear polysaccharides consisting of repeating disaccharide units and are important components of the extracellular matrix (ECM) either in free form (hyaluronan) or as a component of proteoglycans. The latter are complex macromolecules containing a core protein with one or more covalently bound gycosaminoglycan chains such as chondrotin sulphate and heparan sulphate. The ECM is made up of huge multi-molecular complexes with arrays of link proteins and aggrecan molecules along a central hyaluronan backbone. Hyaluronan (HA) is bound by a number of ECM and cell surface proteins, and is a particularly important component of the ECM (Toole 1990; Milner and Day 2003; Laurent et al. 1996; Hardingham and Muir 1972; Camenisch et al. 2000). HA is involved in moderating many cellular processes including proliferation, migration, adhesion and apoptosis (Laurent and Fraser 1982; Toole 1982; Thorne et al. 2004; Misra et al. 2008; Toole and Slomiany 2008; Turley et al. 2002). Large molecular mass fragments of $\mathrm{HA}$ are involved in 
space-filling and immunosuppressive roles, whilst smaller HA fragments have been shown to be proinflammatory and angiogenic and oligosaccharides may be involved in cell signalling (reviewed by Stern et al. 2006).

Oxidative damage of the extracellular matrix components by either enzymatic or non-enzymatic pathways may have implications for the initiation and progression of a range of human diseases. These include arthritis, kidney disease, cardiovascular disease, lung disease, periodontal disease and chronic inflammation. Oxidative damage to $\mathrm{HA}$ by reactive oxidative species (ROS) has been the subject of numerous studies (reviewed by Parsons 1994). The potential mechanism of oxidative damage to the ECM and its role in human pathologies has also been discussed in a recent review (Rees et al. 2008).

The purpose of the current review is show how the principles and techniques of radiation chemistry have enabled the direct reactions of free radicals with biomolecules and biomaterials to be investigated at the molecular level. Such knowledge has also allowed radiation protecting systems to be developed so that sterilising doses of radiation can be delivered to sensitive biomolecules such as proteins and glycosaminoglycans, and also to sensitive biomaterials such as tissue allografts. This review also highlights the pioneering work in all these areas by Professor Glyn O Phillips. The author acknowledges the enormous help and encouragement given to him by Professor Phillips over several decades which have allowed the author to continue and develop their joint interest in the interaction of free radicals with glycosaminoglycans. In a parallel joint interest, the author also has benefitted greatly from Professor Phillips' worldwide network in the field of radiation studies and in particular from his close involvement with the International Atomic Energy Agency (IAEA).

\section{Viscoelastic studies of the free radical degradation of hyaluronan}

The relatively high viscosity of low concentrations of hyaluronan in aqueous solution has made viscometry the method of choice for much of the earlier investigations of degradation of hyaluronan by reactive oxidative species. Thus, as shown in an earlier review in 1994, viscometric methods were dominant (Parsons 1994). Simple capillary viscometers could be used and flow times of degraded hyaluronan solutions were shown to decrease with increase in the amount of reacting oxidant. Although convenient and simple to use, measurements of the efficiency of degradation by a particular oxidant were not calculated. However, in 1987, Myint et al. (1987) used the Mark-Houwink equation to calculate molecular weight changes of hyaluronan solutions and so were able to calculate the concentration of HA chain breaks. The MarkHouwink equation relates intrinsic viscosity to average molecular weight as follows:

$[\eta]=\mathrm{KM}^{\mathrm{a}}$

where $\mathrm{M}$ is the average molecular weight and $\mathrm{K}$ and a are constants with values of 0.029 and 0.8 respectively in $0.15 \mathrm{M} \mathrm{NaCl}$ (Wedlock et al. 1983). From these measurements, the number of chain breaks, $\mathrm{CB}$, was given by;

$\mathrm{CB}=\left(\mathrm{M}^{0}-\mathrm{M}\right) / \mathrm{M}$

where $\mathrm{M}^{0}$ and $\mathrm{M}$ are the molecular weights at zero and non-zero concentrations of oxidant respectively. The concentration of chain breaks, [CB], is then given by;

$[\mathrm{CB}]=\mathrm{CB} \times[\mathrm{HA}]$

These workers used ionising radiation to produce hydroxyl radicals in known concentrations and thus made the first measurement of hyaluronan chain breakage efficiency, a value of $30 \%$ in de-aerated solution being found.

\section{Size exclusion studies of HA degradation}

In an early study using the combined Gel Permeation Chromatography (GPC)/MALLS (Multi-Angle Laser Light Scattering) technique, HA de-polymerisation after reaction with peroxynitrite produced a molecular weight distribution for each peroxynitrite concentration (Al-Assaf et al. 2003). From these distributions, a number average molecular weight could be determined and hence the concentration of HA chain breaks calculated via Eqs. 2 and 3. From the effects of both peroxynitrite and hyaluronan concentrations on the concentration of HA chain breaks, it was deduced that at low HA concentrations, chain breaks could be attributed to hydroxyl radicals arising from the caged 
pair, $\left[\mathrm{OH} \mathrm{NO}_{2}\right]$ and where $5 \%$ of the peroxynitrite concentration produced hydroxyl radicals. At high HA concentrations, for example at $5.3 \mathrm{mM}$ disaccharide, an additional yield of HA chain breaks equal to $3.5 \%$ per peroxynitrite concentration was observed attributable to a reaction of $\mathrm{ONOOH}$ with $\mathrm{HA}$.

GPC/MALLS has also been used to determine the HA chain break efficiencies of the following free radicals; $\mathrm{OH}, \mathrm{Br}_{2}^{--}, \mathrm{Cl}_{2}^{--}, \mathrm{CO}_{3}^{--}, \mathrm{N}_{3}^{-}$where the latter were produced by the gamma irradiation of aqueous solutions (Al-Assaf et al. 2006). The efficiencies ranged from $<2$ to $52 \%$ for the azide and hydroxyl radicals respectively. The presence of oxygen lowers the yields found for the hydroxyl and dichloride anion radicals. In oxygen, the reactions of the initiallyproduced carbon-centred radicals with oxygen are rapid and close to diffusion-controlled limits and lead to the formation of peroxy radicals which on average are presumably less efficient at producing chain breaks. Hydroxyl radicals are the most efficient in causing breakage of the glycosidic bonds in HA and can be expected to abstract hydrogen atoms at all the $\mathrm{C}-\mathrm{H}$ bonds in the HA molecule, with each so-formed $\mathrm{C}$-centred radical having a specific individual chain break efficiency. Hydroxyl radicals can be also expected to react in different proportions at each of the $\mathrm{C}-\mathrm{H}$ bonds depending upon the ease of hydrogen abstraction and so the overall efficiency of chain breakage at a specific $\mathrm{CH}$ bond is a product of these proportions and the efficiency of chain breakage. It is thus clear that, like in the reaction of bromide anion radicals with 2-deoxy-D-ribose, where hydrogen abstraction was highly selective at either $\mathrm{C}-1$ or C-2 or both (Parsons et al. 1978), hydroxyl radicals are also likely to react with some degree of specificity. Given the relatively high average values of chain break efficiency found for hydroxyl radicals, it is likely that chain break efficiencies much higher than the average and perhaps close to $100 \%$ may be anticipated for one or two of the $\mathrm{C}-\mathrm{H}$ bonds (or indeed at the $\mathrm{N}-\mathrm{H}$ bond) in HA. The other radicals used in this study were found to react 2 or 3 orders of magnitude lower than that of hydroxyl radicals and are thus likely to be more selective in the site of hydrogen abstraction, presumably accounting for the $20-21 \%$ chain break efficiencies found for $\mathrm{Br}_{2}^{--}$and $\mathrm{CO}_{3}^{--} \cdot \mathrm{Cl}_{2}^{--}$, like chlorine and hypochlorite, may instead react selectively at the $\mathrm{N}-\mathrm{H}$ to produce a higher chain break efficiency.
In conclusion, the combination of size exclusion chromatography MALLS is probably the most direct and informative technique to monitor the changes in both the molecular weight distribution and size of glycosaminoglycans as they are degraded and depolymerised by the range of oxidative systems in use. When the concentrations of reacting oxidants can be measured quantitatively, as, for example, when free radicals are produced by ionising radiation, chain break efficiencies can be determined and this information can then be used in combination with other data such as rate constants to provide an enhanced insight into the likely molecular mechanisms prevailing. The technique requires both the purchase of expensive equipment as well as time-consuming preequilibration of chromatographic columns. In contrast, gel electrophoresis is usually more productive in terms of sample throughput. To this end, SEC (Size Exclusion Chromatography)/MALLS has been used to provide a molecular weight calibration for gel electrophoresis, as was shown by Sibanda et al. (2013a).

\section{Chloramide derivatives of glycosaminoglycans}

Inflammation of the ECM produces, amongst other oxidizing agents, hypochlorite which can convert the $\mathrm{NH}$ groups in glycosaminoglycans to $\mathrm{NCl}$ groups, the chloramide derivative.

A combination of gamma irradiation and PAGE techniques was used to study the reactions of hydroxyl, carbonate and nitrogen dioxide radicals with the chloramide derivatives of both hyaluronan and the heavily-charged and sulphated heparin (Sibanda et al. 2013a). The $\mathrm{N}-\mathrm{Cl}$ group in the chloramides is a potential selective target for both reducing and oxidising radicals, leading possibly to more efficient and damaging fragmentation of these biopolymers relative to the parent glycosaminoglycans. Polyacrylamide Gel Electrophoresis (PAGE) gels, calibrated for molecular weight, allowed the consequent fragmentation efficiencies of these radicals to be calculated. To calibrate the Rf values in the PAGE scans for molecular mass, solutions of hyaluronan and heparin were irradiated in order to fragment these biomolecules. Irradiation doses of up to $100 \mathrm{~Gy}$ were delivered and the molecular weight distribution 
determined using the GPC/MALLS technique. These solutions were also subjected to PAGE. By matching the molecular weight distribution from the GPC/ MALLS experiments to the PAGE scans, correlations of molecular mass versus Rf were obtained. Thus, the strongly-reducing hydrated electrons were found to react efficiently with the $\mathrm{N}-\mathrm{Cl}$ group in the chloramides with fragmentation efficiencies of 100 and $25 \%$ [expressed as ( $\mathrm{HACl}$ or $\mathrm{HepCl}$ chain breaks)/ (radical)] being determined for hyaluronan chloramide $(\mathrm{HACl})$ and heparin chloramide $(\mathrm{HepCl})$, respectively. The role of the sulphate group in heparin in the reduction of fragmentation was rationalised using mechanisms proposed by Rees et al. (2003) in which the initial formation of an amidyl radical leads rapidly to a C-2 radical on the glucosamine moiety. The latter is $100 \%$ efficient in causing glycodsidic bond breakage in $\mathrm{HACl}$ but only $25 \%$ in $\mathrm{HepCl}$, the role of the sulphate group being to favour the nonfragmentory routes for the C-2 radical. The weaker reducing agent, the superoxide radical, did not cause fragmentation of either $\mathrm{HACl}$ or $\mathrm{HepCl}$ although reactivity had been demonstrated in earlier studies (Rees et al. 2004).

In the same study, experiments producing the oxidizing radicals, hydroxyl and carbonate, both potential in vivo species, showed significant increases in fragmentation efficiencies for both $\mathrm{HACl}$ and $\mathrm{HepCl}$, relative to the parent molecules (Sibanda et al. 2013a). It was proposed that the carbonate radical is involved in site-specific reactions at the $\mathrm{N}-\mathrm{Cl}$ groups, reacting via abstraction of $\mathrm{Cl}$, to produce the same amidyl radical as produced by one-electron reductants such as the hydrated electron. Like hydrated electrons, the data supported fragmentation efficiencies of 100 and $29 \%$ for reaction of carbonate radicals at $\mathrm{N}-\mathrm{Cl}$ for $\mathrm{HACl}$ and $\mathrm{HepCl}$ respectively. For the weaker oxidant, nitrogen dioxide, no fragmentation was observed, probably attributable to a low kinetic reactivity and low reduction potential.

It was concluded that the $\mathrm{N}-\mathrm{Cl}$ group can direct damage to extracellular matrix glycosaminoglycan chloramides which may be produced under inflammatory conditions. The in vivo species, the carbonate radical, was proposed to be much more likely to be site-specific in its reactions with such components of the ECM than the hydroxyl radical (Sibanda et al. 2013a).

\section{Kinetic studies of the free radical depolymerisation of glycosaminoglycans and their chloramide derivatives}

\section{Mixing and stopped flow techniques}

The stopped flow technique has been used to measure the rates of disappearance of the peroxynitrite absorption at $302 \mathrm{~nm}$ in HA solutions (Al-Assaf et al. 2003). These reactions were followed typically up to $5 \mathrm{~s}$. This study confirmed that fragmentation came from two routes; one via the isomerisation of $\mathrm{ONOOH}$ to produce hydroxyl radicals and the other via a direct reaction of $\mathrm{ONOOH}$ with $\mathrm{HA}$ with a rate constant of $10 \mathrm{M}^{-1} \mathrm{~s}^{-1}$.

The reaction of hyaluronan with hypochlorite/ hypochlorous acid mixtures was sufficiently slow to allow the a more detailed study to be carried out using the simple mixing of reactants and observing the decay of optical absorption of the hypochlorite species over relatively long timescales, in some cases up to $400 \mathrm{~min}$ (Akeel et al. 2013). Reactions with hylauronan and heparin (as a model for sulphated glycosaminoglycans in the extracellular matrix) were studied at $25{ }^{\circ} \mathrm{C}$ as a function of $\mathrm{pH}$ allowing the rates of the separate reactions of hypochlorite $\left(\mathrm{OCl}^{-}\right)$and $\mathrm{HOCl}$ to be measured. Spectral, chloramide yield and kinetic measurements showed sharply contrasting behaviour of heparin and hyaluronan. At low concentrations of hypochlorite, $\mathrm{N}-\mathrm{Cl}$ yields were $100 \%$ for the hyaluronan with both $\mathrm{OCl}^{-}$and $\mathrm{HOCl}$ and the respective second-order rate constants were determined as $1.0 \times 10^{-2}$ and $1.7 \times 10^{-2} \mathrm{M}^{-1} \mathrm{~s}^{-1}$ respectively. At high concentrations of hypochlorite, evidence of a reaction between the hypochlorite species and hyaluronan chloramide was given, where the respective rate constants for $\mathrm{HOCl}$ and $\mathrm{OCl}^{-}$were $3.0 \times 10^{-2}$ and $6.0 \times 10^{-3} \mathrm{M}^{-1} \mathrm{~s}^{-1}$. For heparin, there was however no evidence of analogous reactions at high hypochlorite concentrations. At low concentrations, in contrast to hyaluronan, the observed rates of decay of hypochlorite species were higher at low $\mathrm{pH}$ (6.5) than at higher $\mathrm{pH}$ (8.5). Further, the chloramide yields decreased from 94 to $60 \%$, implying that there are significant competitive non-chloramide producing pathways at all pHs. Separate second-order rate constants for the reactions of both $\mathrm{OCl}^{-}$and $\mathrm{HOCl}$ to produce the chloramide and non-chloramide products were thus determined. Thus, unlike heparin, the 
electrostatically neutral acetyl-N-H group in hyaluronan does not provide any electrostatic effect on the efficiency of $\mathrm{N}-\mathrm{Cl}$ production in the direct reaction between hypochlorite species and hyaluronan. In contrast, the presence of the $\mathrm{N}-\mathrm{SO}_{3}{ }^{-}$in heparin provides a negative electrostatic effect on the rate of reaction, particularly apparent in the $\mathrm{OCl}^{-}$reaction, which leads to significant proportions of hypochlorite, up to $40 \%$, participating in nonchloramide producing pathways. By comparison with hyaluronan, it can be demonstrated that both $\mathrm{N}$-sulphate and $\mathrm{O}-$ sulphate groups in heparin influence the proportions of these pathways in heparin. This study also provided evidence that at high concentrations of hypochlorite, the formation of the chloramide product of hyaluronan presents a more reactive target than hyaluronan itself.

Pulse radiolysis and laser flash photolysis

One of the earliest kinetic studies of the reaction of oxidative species with hyaluronan was a pulse radiolysis study initiated by Professor Phillips (Balazs et al. 1968). In pulse radiolysis, a short pulse (usually $5-100 \mathrm{~ns})$ of high energy electrons $(2-10 \mathrm{MeV})$ is given to a quartz cell containing an aqueous solution containing various solutes under investigation. The primary radiolytic species are produced within the timespan of the pulse by the effect of ionising radiation on the solvent, water. These radicals can then react on longer timescales, typically from $500 \mathrm{~ns}$ to $500 \mathrm{~ms}$ and the light absorption parameters of transient species formed by reaction of the primary species can be detected by photodetectors, usually collected as absorbance at a single wavelength versus time. From a set of such kinetic traces, a complete description of the transient spectral changes versus time can be assembled. Using the pulse radiolysis technique, and using nitrous oxide saturated solutions to convert hydrated electrons into hydroxyl radicals, the second-order rate constants for the reaction of hydroxyl radicals with any substrate can be determined. In this early study, the rate constant for the reaction of hydroxyl radicals with heparin was found to be $2.2 \times 10^{8} \mathrm{M}^{-1} \mathrm{~s}^{-1}$ (Balazs et al. 1968). A similar pulse radiolysis study on hyaluronan yielded a value of $7 \times 10^{8} \mathrm{M}^{-1} \mathrm{~s}^{-1}$ (Myint et al. 1987). Pulse radiolysis was again used to measure the kinetic reactivities of several radicals with hyaluronan (Al-Assaf et al. 2006). Hydroxyl radicals can be used to generate carbonate radicals through their reaction with hydrogen carbonate anions. In addition, azide, dibomide and dichloride radical anions were produced, as follows:

$$
\begin{aligned}
& \mathrm{OH}+\mathrm{N}_{3}^{-} \rightarrow \mathrm{N}_{3}^{-}+\mathrm{OH}^{-} \\
& \mathrm{OH}+2 \mathrm{Br}^{-} \rightarrow \mathrm{Br}_{2}^{--}+\mathrm{OH}^{-} \\
& \mathrm{OH}+2 \mathrm{Cl}^{-} \rightarrow \mathrm{Cl}_{2}^{--}+\mathrm{OH}^{-}
\end{aligned}
$$

The rates of reaction of carbonate, dichloride anion and dibromide anion radicals were measured from the decay of their optical aborptions at 600, 340 and $360 \mathrm{~nm}$ respectively. For azide radicals, whose optical absorption is weak, the competition kinetics approach was used by following the rate of formation of the highly-absorbing chlorpromazine cation radical. The rate constants thus determined were $7 \times 10^{5}\left(\mathrm{CO}_{3}^{--}\right)$, $6.9 \times 10^{6}\left(\mathrm{Cl}_{2}^{-}\right), 1 \times 10^{6}\left(\mathrm{Br}_{2}^{-}\right)$and $<10^{5} \mathrm{M}^{-1} \mathrm{~s}^{-1}$ $\left(\mathrm{N}_{3}\right)$. All of these oxidative species react with hyaluronan 2-3 orders of magnitude more slowly than hydroxyl radicals. Hence, for the more biologically relevant carbonate radical, a much higher degree of selectivity of attack with glycosaminoglycans is to be expected, as confirmed in fragmentation studies (Sibanda et al. 2013a).

The reactivities of both oxidizing and strongly reducing radicals with the chloramide derivatives of hyaluronan and heparin were investigated using both pulse radiolysis and laser flash photolysis techniques (Sibanda et al. 2013b). The strong reducing agent, the formate radical was produced by both pulse radiolysis and by laser flash photolysis. In the former technique, nitrous oxide saturated solutions of $0.1 \mathrm{M}$ formate containing a range of concentrations of chloramide concentrations were pulse-irradiated. Under these conditions, all primary radiolysis radicals produce formate radicals via reactions 4 and 5 followed by reactions 7 and 8 .

$$
\begin{aligned}
& \mathrm{OH}+\mathrm{HCOO}^{-} \rightarrow \mathrm{CO}_{2}^{--}+\mathrm{H}_{2} \mathrm{O} \\
& \mathrm{H}+\mathrm{HCOO}^{-} \rightarrow \mathrm{CO}_{2}^{--}+\mathrm{H}_{2}
\end{aligned}
$$

Using laser flash photolysis, the formate radical was formed by a $10 \mathrm{~ns}$ laser excitation at $266 \mathrm{~nm}$ of nitrogen saturated solutions containing $30 \mathrm{mM}$ persulphate $\left(\mathrm{S}_{2} \mathrm{O}_{8}{ }^{2-}\right)$ and $10-50 \mathrm{mM}$ formate $\left(\mathrm{HCOO}^{-}\right)$. Here, sulphate anion radicals $\left(\mathrm{SO}_{4}^{-}\right)$are produced 
rapidly via excitation of persulphate with a quantum efficiency close to 2 and exhibit a peak of maximum absorbance at $455 \mathrm{~nm}$.

$\mathrm{S}_{2} \mathrm{O}_{8}^{2-} \rightarrow 2 \mathrm{SO}_{4}^{--}$

In the presence of formate, $\mathrm{SO}_{4}^{--}$oxidises formate rapidly to $\mathrm{CO}_{2}^{--}$.

$\mathrm{SO}_{4}^{--}+\mathrm{HCOO}^{-} \rightarrow \mathrm{CO}_{2}^{--}+\mathrm{SO}_{4}^{2-}+\mathrm{H}^{+}$

By monitoring the rate of growth of optical absorption in the range $300-400 \mathrm{~nm}$ attributable to transient free radical products from the subsequent reactions of the formate radical with the chloramides, $\mathrm{HACl}$ and $\mathrm{HepCl}$, rate constants of (1-1.7) $\times 10^{8}$ and $(0.7-1.2) \times 10^{8} \mathrm{M}^{-1} \mathrm{~s}^{-1}$ for were determined respectively.

Hydrated electrons, $\mathrm{e}_{\mathrm{aq}}^{-}$, the strongest reducing radicals, were generated by pulse radiolysis of argon-saturated 0.1 M tert-butanol solutions containing a range of chloramide concentrations. In the presence of tert-butanol, hydroxyl radicals are scavenged to produce non-reactive species, allowing the reactivity of the hydrated electron to be studied independently by following the decay of its absorption at $720 \mathrm{~nm}$. The rate constants were thus determined as $2.2 \times 10^{9}$ and $7.2 \times 10^{8} \mathrm{M}^{-1} \mathrm{~s}^{-1}$ for $\mathrm{HACl}$ and $\mathrm{HepCl}$ respectively. As with formate radicals, transient free radicals products absorbing in the range 300-400 nm were observed. The spectral characteristics of the products of both formate and hydrated electron reactions were identical and were consistent with initial attack at the $\mathrm{N}-\mathrm{Cl}$ groups, followed by rapid elimination of chloride ions and formation of nitrogen-centred radicals, which then re-arrange rapidly to produce $\mathrm{C}-2$ radicals on the glucosamine moiety supporting an earlier EPR study (Rees et al. 2003).

The oxidising hydroxyl radicals, produced by pulse radiolysis and whose rates of reaction were monitored using $\mathrm{ABTS}^{2-}$ as a competing substrate (yielding the highly-absorbing $\mathrm{ABTS}^{-}$) also reacted rapidly with $\mathrm{HACl}$ and $\mathrm{HepCl}$ with rate constants of $2.2 \times 10^{8}$ and $1.6 \times 10^{8} \mathrm{M}^{-1} \mathrm{~s}^{-1}$, with no evidence from this data for any degree of selective attack for the $\mathrm{N}-\mathrm{Cl}$ group relative to the $\mathrm{N}-\mathrm{H}$ groups and other sites of attack. The oxidizing carbonate radicals were produced by laser flash photolysis (excitation at $266 \mathrm{~nm}$ ) of airsaturated $30 \mathrm{mM}$ persulphate solutions containing
$300 \mathrm{mM}$ bicarbonate at $\mathrm{pH} 8.5$ which produced high yields of the carbonate anion radical, $\mathrm{CO}_{3}^{--}$, via the following reaction:

$\mathrm{SO}_{4}^{--}+\mathrm{HCO}_{3}^{-} \rightarrow \mathrm{CO}_{3}^{--}+\mathrm{SO}_{4}^{2-}+\mathrm{H}^{+}$

The carbonate anion radical, $\mathrm{CO}_{3}^{--}$, exists in equilibrium with the protonated form, $\mathrm{HCO}_{3}$ with a $\mathrm{p} K_{\mathrm{a}}$ of 7.9 (Eriksen et al. 1985).

$\mathrm{HCO}_{3} \rightarrow \mathrm{CO}_{3}^{--}+\mathrm{H}^{+}$

Upon laser flash photolysis of the persulphate/ bicarbonate solution, the carbonate anion radical was formed within several microseconds and its formation and decay were monitored kinetically at $600 \mathrm{~nm}$. Carbonate anion radicals were found to react much slower with $\mathrm{HACl}$ and $\mathrm{HepCl}$ than hydroxyl radicals $\left(1.0 \times 10^{5}\right.$ and $8.0 \times 10^{4} \mathrm{M}^{-1} \mathrm{~s}^{-1}$, respectively) but significantly faster than with the parent molecules $\left(3.5 \times 10^{4}\right.$ and $5.0 \times 10^{4} \mathrm{M}^{-1} \mathrm{~s}^{-1}$, respectively) These findings suggested that these potential in vivo oxidizing radicals, particularly the carbonate radical, may react in a site-specific manner with the $\mathrm{N}-\mathrm{Cl}$ group in the glycosaminoglycan chloramides. For the strongly-reducing species, formate radicals and hydrated electrons, the reactions with the chlroamidesare $100 \%$ site-specific, attacking only the $\mathrm{N}-\mathrm{Cl}$ group and releasing chloride ion in $100 \%$ yield as confirmed in other pulse radiolysis studies on chloramines (Poskrebyshev et al. 2003; Pattison et al. 2002, 2011).

The rates of reactions of the superoxide radical, $\mathrm{O}_{2}^{--}$, with $\mathrm{HACl}$ and $\mathrm{HepCl}$ were investigated using laser flash photolysis by excitation, at $266 \mathrm{~nm}$, of solutions containing $30 \mathrm{mM}$ persulphate $\left(\mathrm{S}_{2} \mathrm{O}_{8}{ }^{2-}\right)$ and $10-50 \mathrm{mM}$ formate $\left(\mathrm{HCOO}^{-}\right)$in the presence of either air or oxygen and $50 \mu \mathrm{M}$ EDTA (Parsons et al. 2013). Superoxide radicals are thus formed via reactions 12 and 13 followed by:

$\mathrm{CO}_{2}^{--}+\mathrm{O}_{2} \rightarrow \mathrm{O}_{2}^{--}+\mathrm{CO}_{2}$

The superoxide radical exists in equilibrium with its protonated form, $\mathrm{HO}_{2}(\mathrm{pKa}=4.8)$ (Bielski et al. 1985):

$\mathrm{HO}_{2} \leftrightarrow \mathrm{O}_{2}^{--}+\mathrm{H}^{+}$

At $\mathrm{pHs}$ above the $\mathrm{pKa}$ therefore, the principal species is the superoxide radical anion. The major route for its decay in the absence of substrates is via 
reaction with its protonated form, $\mathrm{HO}_{2}$. As the $\mathrm{pH}$ is increased, it has been shown that the observed secondorder rate constant decreases logarithmically (Bielski et al. 1985). By observing the effect of $\mathrm{HACl}$ and $\mathrm{HepCl}$ concentrations on the decay of superoxide radicals produced upon laser flash photolysis, the rate constants for the direct reaction of superoxide radicals with the chloramides of hyaluronan and heparin were measured for the first time and found to be in the range 2.2-2.7 $\times 10^{3} \mathrm{M}^{-1} \mathrm{~s}^{-1}$. An additional approach in the same study (Parsons et al. 2013) to determine the rate of reaction of superoxide with the glycosaminoglycan chloramides involved monitoring the rate of reduction of ferricytochrome c (cyt c) at $550 \mathrm{~nm}$ in the absence and presence of the latter substrates. Laser flash photolysis of oxygenated solutions containing $30 \mathrm{mM}$ persulphate, $50 \mathrm{mM}$ formate, $50 \mu \mathrm{M}$ cyt $\mathrm{c}$, $50 \mu \mathrm{M}$ EDTA at $\mathrm{pH} 9.5$ produced a growth in absorbance at $550 \mathrm{~nm}$ over $1 \mathrm{~s}$ and was assigned to the reduction of ferricytochrome $\mathrm{c}$ by superoxide. The addition of $\mathrm{HACl}$ and $\mathrm{HepCl}$ allowed the rates of reaction of superoxide with the chloramides to be measured via competitive kinetics. The rate constants were identical to those found by the direct measurement of superoxide decay. In a previous study using SOTS-1 to react with the chloramides of hyaluronan and chondroitin sulphates, it was concluded, through the inhibitory effect of EDTA, that the superoxide reaction was mediated, at least in part, by $\mathrm{Cu}_{\mathrm{aq}}^{2+}$ (Rees et al. 2004), presumably through the redox cycling of $\mathrm{Cu}$ (II) and $\mathrm{Cu}(\mathrm{I})$ leading to reduction of the $\mathrm{N}-\mathrm{Cl}$ group by $\mathrm{Cu}(\mathrm{I})$. An identical conclusion was also made for the chloramines and chloramides of heparin sulphate (Rees and Davies 2006). This indirect mechanism for reaction of superoxide with glycosaminoglycan chloramides may be in competition with the direct reaction demonstrated in the laser flash photolysis study (Parsons et al. 2013). At the relatively low concentrations of chloramides, $200-300 \mu \mathrm{M}$ used in the earlier studies (Rees et al. 2004; Rees and Davies 2006; Hawkins et al. 2002), as little as $1 \mathrm{nM}$ of $\mathrm{Cu}_{\mathrm{aq}}^{2+}$ involved in effective redox cycling at $\mathrm{pH} 7.4$ would be the main channel of reaction, since superoxide reacts at diffusion-controlled rates with $\mathrm{Cu}$ (I/II) aquo complexes. At the $\mathrm{pH}$ of 9.5 and the higher chloramide and chloramine concentrations used in the laser flash photolysis study, the direct reaction is dominant.

\section{Sterilisation of sensitive biomolecules in aqueous solution}

In contrast to the considerable amount of research literature on the inactivation of enzymes and on the degradation of proteins in general, there have been relatively few studies which have focused on the sterilisation and/or the degradation of proteins and enzymes at doses close to typical sterilisation doses (25 kGy). For aqueous preparations, these studies have adopted a dual approach to protection of proteins, i.e. protein solutions have been irradiated in the presence of a free radical scavenger as well as being frozen. Some of these studies have also been conducted in the solid state, as lyophilized or dry samples. When aqueous solutions are irradiated in the frozen state, the primary free radicals of water and their precursors become trapped. At low temperatures, diffusion of these precursors and their products is very restricted reducing the possibility of interaction with substrates and thus the precursors are able to recombine reducing the yields of hydroxyl, hydrated electrons and hydrogen when solutions are thawed. It is clear therefore, that the yields of primary waterderived free radicals and molecular species available to react with substrates such as proteins are much reduced when frozen aqueous solutions are irradiated. Irradiation at low temperatures in frozen solution is therefore very desirable in that free radical-induced degradation is much reduced although not necessarily non-existent. At low temperatures in frozen solutions, it has been shown that the inactivation of an enzyme, such as invertase, using very large doses up to $900 \mathrm{kGy}$ (Kempner 2001), is described by the following equation:

$\mathrm{A}=\mathrm{A}_{0} \mathrm{e}^{-\mathrm{qmD}}$

where $\mathrm{D}$ is the radiation dose, $\mathrm{m}$ is the molecular mass of the enzyme (or target) and $\mathrm{q}$ is a constant related to average energy deposition in each primary ionization and also to a factor reflecting the change in radiation sensitivity with temperature. Essentially, this equation is a quantitative description of the direct effect of radiation on a large target molecule such as a protein and is in fact usually referred to as the target theory of radiation (see for example Lowe and Kempner 1982). In this theory, it is assumed that each random ionisation of a protein molecule results in massive 
structural damage and complete loss of biological function. Thus, it was observed that there was little or no detectable loss in invertase activity on extrapolation to a typical sterilisation dose of $25 \mathrm{kGy}$ (Kempner 2001).

Adopting this dual approach of irradiating proteins and enzymes at a low temperature in the presence of a free radical scavenger, insulin monoclonal antibody preparations were irradiated at $4{ }^{\circ} \mathrm{C}$ at doses of 15 and $45 \mathrm{kGy}$ in the presence and absence of $0.2 \mathrm{M}$ ascorbate (Grieb et al. 2002). In the absence of ascorbate, SDS PAGE and ELISA experiments showed that there was almost complete loss of activity and protein at both 15 and $45 \mathrm{kGy}$ doses. Although there is insufficient detail in this paper to calculate the concentration of the antibody, these experiments show that there is considerable damage to the protein even at $4{ }^{\circ} \mathrm{C}$. It is not clear however whether these solutions were actually frozen or still liquid. It seems likely that the indirect production of the primary water-derived free radicals is still significant and that diffusion of them to react with the protein was still taking place. In the presence of ascorbate at $4{ }^{\circ} \mathrm{C}$, there was no detectable loss of antibody activity at $15 \mathrm{kGy}$ although some loss could be measured at $45 \mathrm{kGy}$. Protein bands were observed using SDS-PAGE showing that the loss of protein had been reduced considerably. Freezedried solutions of the antibody irradiated in the presence of ascorbate showed full retention of activity at $15 \mathrm{kGy}$ with some reduction in activity at $45 \mathrm{kGy}$. No measurements of retention of protein integrity were made in this case because a 100-fold excess of a bulking agent, albumin, was added to facilitate freezedrying. The authors also showed that the radiationinduced aggregation of antibody, clearly observed in size exclusion experiments in the absence of ascorbate, was not apparent in the presence of ascorbate. Experiments were carried out at lower temperatures, $-80{ }^{\circ} \mathrm{C}$, but only to show the effect of ascorbate on the reduction of levels of virus in frozen solutions spiked with the pathogen. In a similar study (Amareld et al. 2003), urokinase was irradiated at $-80{ }^{\circ} \mathrm{C}$ at a dose of $50 \mathrm{kGy}$. Here, in the presence of $0.2 \mathrm{M}$ ascorbate, the activity of the enzyme was maintained at about $90 \%$ of the unirradiated control frozen solution. The same solution spiked with virus and then irradiated showed reduced levels of pathogen by about five orders of magnitude. In the absence of ascorbate, the activity was reduced to about $20 \%$ of the control. No attempts were made in that study to monitor the loss of integrity of the protein after irradiation. The fact that enzyme function is reduced considerably in the absence of ascorbate confirms: (1) that ascorbate is an effective free radical scavenger, presumably in these conditions, of the hydroxyl radical, and (2) that at $-80{ }^{\circ} \mathrm{C}$ in the absence of ascorbate, the loss of enzyme activity is probably much greater than could be expected from the direct action of radiation alone on the enzyme (Lowe and Kempner 1982). It seems likely therefore that there is a significant contribution from trapped water-derived free radicals arising from direct action of radiation on the solvent, water.

Irradiation of human plasma at high sterilisation doses, $50 \mathrm{kGy}$, at dry ice temperatures of approximately $-80{ }^{\circ} \mathrm{C}$ in the presence of $12.5-50 \mathrm{mM}$ ascorbate has been investigated by using the formation of protein hydroperoxides and carbonyls as markers of damage to the proteins (Zbikowska et al. 2006). In the absence of ascorbate but at dry ice temperatures, there was an approximately twofold reduction in the level of radiation induced protein hydroperoxides relative to the same solution irradiated at ambient temperature (as estimated from the low doses used common to both experiments). This may be due to the difference in oxygen concentrations in the two experiments and this may make comparison difficult since oxygen is required for hydroperoxide formation. It is also not clear whether protein oxidation $-80{ }^{\circ} \mathrm{C}$ is attributable to direct action on plasma proteins or from trapped water-derived free radicals. At $1 \mathrm{mg} / \mathrm{ml}$ plasma protein, the amino acid concentration is relatively high and may be sufficient to scavenge significant amounts of trapped water-derived free radicals. In the presence of ascorbate at $-80{ }^{\circ} \mathrm{C}$, there was an approximately $30 \%$ reduction in carbonyl formation. This reduction is very small and may be accounted for by the high concentration of protein, effectively in competition with ascorbate, or, as the authors indicate, the situation may be more complex since ascorbate itself may reduce the levels of carbonyl and hydroperoxide subsequent to their formation on irradiation. Subsequent studies by the same workers using a $50 \mathrm{kGy}$ dose and dry ice and focusing on protein degradation, in particular, on fibrinogen, and plasminogen, as well as on the coagulation and fibrinolytic activities of plasma, have confirmed the relatively small protective effect of $50 \mathrm{mM}$ ascorbate. Surprisingly, a much greater protective effect was 
observed for $50 \mathrm{mM}$ histidine (Zbikowska et al. 2007a, b).

Immunoglobulins, in the form of recombinant monoclonal or polyclonal antibodies derived from blood plasma, have also been irradiated at sterilising doses at dry ice temperatures. Upon irradiation of a paste, it was shown that the Fab and Fc domains of Intravenous Immunoglobulins (IVIG) remain essentially intact. Integrity of these domains was seen as a critical requirement for a successful application of a radiation sterilisation process, primarily designed to eliminate harmful viral agents (Tran et al. 2004).

In a study of the sterilisation of $\beta$-galactosidase, tris buffer and nitrite ions were used as radiation protection agents-the irradiations being carried out under inert conditions (nitrogen de-gassing of solutions) and at both ambient and dry ice temperatures (AudetteStuart et al. 2005). Nitrite ions are good scavengers of electrons, of both "dry" and hydrated forms, as well as being scavengers of hydrogen atoms. These reactions produce nitrogen dioxide as the major product. Here, tris buffer was used a scavenger of hydroxyl radicals. Analyses of protein degradation and enzyme activity were made. In the presence of nitrite at ambient temperatures, where the indirect effect of the waterderived free radicals dominate the radiation chemistry, the G-values for the loss of enzyme activity increased nearly fourfold on addition of excess nitrate from $8.8 \times 10^{-9} \mathrm{~mol} \mathrm{~J}^{-1}$ to a value of $3.18 \times 10^{-8}$ mol $\mathrm{J}^{-1}$ - the increase being attributable to reactions of nitrogen dioxide which is known to nitrate tyrosine residues. It is notable that both these yields are less than the total yield of hydrated electrons, hydrogen atoms and hydroxyl radicals produced by the direct action of radiation on water (equal to about $6.3 \times 10^{--}$ ${ }^{7} \mathrm{~mol} \mathrm{\textrm {J } ^ { - 1 }}$ ). In addition, the authors also noted that the loss of protein was always less than the loss of enzyme activity. This is an unusual finding and may be attributable to modification of the enzyme with change in molecular mass. Here, nitrogen dioxide may simply nitrate the enzyme without producing fragmentation. At dry ice temperatures and in the absence of nitrite ions, the loss of protein integrity is much reduced relative to ambient temperatures- a reduction of at least 250 -fold was observed. In the presence of nitrate at these temperatures, the loss of protein integrity was reduced by a factor of 45 . In the presence of tris buffer, used as a scavenger of hydroxyl radicals, protection of the protein integrity was also apparent although the effect was not dramatic-for example, at ambient temperatures, addition of tris buffer reduced the loss to $40 \%$ of the solution irradiated in the absence of tris buffer. It may be here that the analysis of protein fragmentation is complicated by protein aggregationhydroxyl radicals are known, for example, to react with tyrosine residues, to yield protein dimers. In the same study, the effect of lyophilisation on protein integrity was also studied. The authors found that at $-78^{\circ} \mathrm{C}$, there was little if any difference in the loss of protein integrity upon lyophilisation. At ambient temperatures, the radiation-induced loss of protein was reduced by a factor of five relative to dilute solutions of the enzyme. It is clear from this study that again reduction of temperature to that of dry ice brings significant reductions in protein damage. It is not clear however, how much of the damage is attributable to trapped water-derived free radicals relative to damage caused by direct action on the enzyme. It can be noted however that molecular mass of $\beta$-galactosidase is high at approximate $500 \mathrm{kDa}$ and this would enhance the potential for significant direct action on the protein at the high sterilisation doses used here. The study probably also confirms that the particular scavengers used are not particularly effective in protecting the enzyme.

In a recent paper on the sterilisation of human insulin, protection of the protein was attempted largely in aqueous solution without resort to either lyophilisation or reduction in temperature (Terryn et al. 2007) and can be compared with a previous study by the same author in which solid-state insulin was irradiated at radiosterilisation doses (Terryn et al. 2006). At $10 \mathrm{kGy}$, the recovery of insulin was $96.8 \%$. In the experiments in aqueous solution, experiments were carried out under nitrogen and at $\mathrm{pH} 2$ (to avoid precipitation of insulin). The most effective protection agents were found to be ascorbate and oxidized glutathione (GSSG). Both insulin degradation and dimer/polymer yields were determined although it was not made clear how the two sets of measurements related to one another. With this proviso, it was shown that at $10 \mathrm{kGy}$ and using $0.34 \mathrm{M}$ ascorbic acid, there was $73.6 \%$ retention of insulin. Additional experiments at dry ice temperatures again confirmed the reduction in radiation-induced degradation of proteins. At $25 \mathrm{kGy}$, the amount of insulin was reduced to about $40 \%$ of the un-irradiated value-at this dose at ambient temperature, there would be no insulin left. 
Nevertheless, the reduction in protein integrity at dry ice temperatures is considerable. However, addition of $0.34 \mathrm{M}$ ascorbic acid led to at least $90 \%$ recovery at this dose.

In these latter, relatively few, focused studies on the sterilisation of proteins, there are several points worthy of note for future sterilisation strategies. It is clear that sterilisation at dry ice temperatures does reduce the protein degradation yields considerably relative to experiments in dilute solution. For the single study where radiation yields were given, the reduction is at least a factor of 100 - the data may in fact underestimate the reduction since protein modification without fragmentation may not have been measurable (Audette-Stuart et al. 2005). Whether this reduction is due entirely to the direct effect of radiation on the enzyme or whether it is attributable to a low yield of waterderived free radicals was not established. It may be that both mechanisms play a part. The addition of free radical scavengers, in particular ascorbate, which is known to react effectively with hydroxyl radicals, also brings about a large reduction in degradation of proteins and enzymes, an effect which is also apparent at dry ice temperatures. In aqueous solutions at ambient temperature, it is the most effective protective agent. That it protects better than other hydroxyl radical scavengers probably indicates that ascorbate not only scavenges free radicals but also repairs damaged amino acid residues. The highly protective effect of ascorbate seen at dry ice temperatures (Terryn et al. 2007) may either indicate that high concentrations of ascorbate can scavenge any free radicals arising from traps in ice or it may also suggest that whatever the mechanism by which damage to amino acid residues arises in the frozen state, ascorbate can repair such damage. Most sterilisation studies have so far focused on scavengers which react with oxidizing species such as the hydroxyl radical, neglecting the significant damage that hydrated electrons can do to proteins. Here, it can be noted that oxidized glutathione at low concentrations $\left(10^{-4} \mathrm{M}\right)$ was shown to an effective protective agent probably reflecting its ability to scavenge hydrated electrons as well as the oxidizing radicals. Finally, lyophilisation of protein solutions was found to confer significant protection relative to dilute solution at ambient temperatures-the loss of protein being reduced by a factor of five (AudetteStuart et al. 2005).

\section{Principles of sterilisation of health care and related products}

The main aim of sterilisation of health care and related products is to reduce the level of pathogens to an acceptable, safe level. In doing so, it is clearly important to minimize damage to the product itselfthe radiation chemicals principles and the methods derived therefrom have been summarised above.

The action of radiation on bacteria, viruses and spores has received much attention in the research literature, largely, in the case of cells, as part of the process of understanding the mechanisms of radiotherapy. Cells, including bacterial cells, are killed by ionizing radiation through damage to DNA. The damage may be attributable to both the indirect effect, arising from water-derived free radicals produced within the cell, and also from the direct effect of radiation on DNA within the cell nucleus. It is unlikely that water-derived free radicals formed outside the cell are lethal. The proportions of indirect to direct effect within cells and viruses have also been the subject of much study and estimates have been made which are close to 50:50 (for example, (von Sonntag 1987; Krisch et al. 1991). That the lethal effects of radiation occur within the cell or virus is a distinct advantage for sterilisation by radiation of healthcare products in solution. Thus, water-derived free radicals produced outside the cells or viruses, can be scavenged. At the same time, the direct effect of radiation on DNA still occurs and so kills cells. There may be some effect of free radical scavengers incorporated within the cell which might reduce the rate of killing and this can be tested and accounted for. The effect of absorbed dose on the inactivation of a population of a specific cell or virus is normally accounted for quantitatively by an exponential relationship:

$\mathrm{N}=\mathrm{N}_{0} 10^{-\left(\mathrm{D} / \mathrm{D}_{10}\right)}$

where $\mathrm{N}$ represents the number of survivors at a dose $\mathrm{D}, \mathrm{N}_{0}$ is the original number of cells or viruses and $\mathrm{D}_{10}$ is the dose required to reduce the number of cells or viruses to $10 \%$. Differences in sizes of the genomes for bacteria, spores and viruses lead to differences in sensitivity to radiation. In general, $\mathrm{D}_{10}$ values for bacteria and spores are lower than those for viruses. Typical $D_{10}$ values for bacteria, for example range from 1 to $4 \mathrm{kGy}$ whereas the typical range for viruses 
is about $3-8 \mathrm{kGy}$. It should be assumed that $\mathrm{D}_{10}$ values are temperature dependent. For the HIV-1 virus, for example, the $\mathrm{D}_{10}$ value was found to be $7.2 \mathrm{kGy}$ at room temperature and $8.3 \mathrm{kGy}$ at $-80{ }^{\circ} \mathrm{C}$ (Hernigou et al. 2000). Other factors may also affect the $D_{10}$ values and it is therefore advisable to determine these values for the particular set of sterilisation conditions.

The quantitative relationship between cell or virus survival and also the ability of commercial gamma radiation sources to deliver accurate doses of radiation enables methods to be developed which can achieve specific Sterility Assurance Levels (SAL) for health care products. These methods were first developed for manufactured health care products such as syringes, sutures, and needles, items produced in large numbers. In the seminal ISO documents on these methods, (International Standard Organization (ISO) 1995a, b), two methods are used to establish radiation doses to achieve SAL values of $10^{-6}$ [i.e. a probability of 1 in $10^{6}$ of there being one survival colony forming unit (cfu) — in the case of bacteria]. Method 1 relies on knowing the bioburden on the product before irradiation-i.e. the cfu values for each type of bacteria should be known. In this method, for bacteria, a Standard Distribution of Resistance (SDR) is assumed. These data are then used to establish a verification dose to achieve a SAL of $10^{-2}$. Delivery of the verification dose and subsequent confirmation that no colony forming units survive then allows a sterilisation dose to achieve a SAL of $10^{-6}$ to be calculated. The method involves a statistical approach to setting the sterilisation dose, requiring the use of relatively large numbers of samples from 3 batches (130) for the establishment of the initial bioburden and verification dose. In Method 2, no assumptions are required concerning the numbers and types of bioburden. Instead, incremental doses are given to samples of the product and the remaining survivors measured. Again, a relatively large number of samples (280) is required to establish a verification dose for an SAL of $10^{-2}$ from which the sterilisation dose required to achieve a SAL of $10^{-6}$ may be calculated. Subsequent methods have been developed with the aim of using smaller numbers of samples for establishing verification doses using of $25 \mathrm{kGy}$ (ISO 1996; AAMI 2001) and more recently for both 15 and $25 \mathrm{kGy}$ doses (ISO 2006a, b, c).

Application of these principles of sterilisation to tissue allografts was undertaken by the International
Atomic Energy Agency through a project involving tissue banks in Asia and Central and South America (IAEA 2004; Parsons et al. 2005). Unlike manufactured health care products, tissue allografts such as amnion and bones have irregular sizes and shape. They are available only in small numbers. There is thus a strong requirement to establish the verification dose and sterilisation dose using small numbers of samples or indeed portions of these (Sample Item Portions; SIPs). Furthermore, their structural integrity may be compromised at large sterilisation doses. The IAEA Code of Practice adopted the principles of dose setting and applied them particularly to the use of small sample numbers and SIPs for verification dose setting. The Code also draws attention to the need for screening of donors to exclude viral contamination as well to the problems relating to non-uniformity of samples. Currently, the Code is now being used by many tissue banks, an example of which can be found in the studies by Yusof and colleagues (Yusof et al. 2007).

Whether manufactured or procured tissue allografts are being sterilised, a common set of principles has been developed and suitable protocols set out. For both types of product, it is essential that the initial bioburden i.e. prior to sterilisation, is maintained at low values. The ability to achieve a SAL of $10^{-6}$ at sterilisation doses of $25 \mathrm{kGy}$ or lower is related quantitatively to the initial bioburden, as expressed for bacteria in cfu values and proportions of bacteria with differing radiation resistances. At initial bioburden levels of more than $1000 \mathrm{cfu}$ for a Standard Distribution of Resistances, for example, it will not be possible to achieve a SAL of $10^{-6}$ at $25 \mathrm{kGy}$. For tissue allografts, maintaining a low initial bioburden depends on the pre-sterilisation techniques used in the tissue bank. Good techniques will ensure that the initial bioburden is low and that in consequence sterilisation doses much lower than $25 \mathrm{kGy}$ may be justified. Similarly, for manufactured products, Good Manufacturing Practice may produce a low initial bioburden. Two approaches in establishing the initial bioburden may be used. Either, it is assumed that a Standard Distribution of Resistances is appropriate, or it is established experimentally that a different and perhaps more radiation sensitive distribution of bacteria exists with its respective range of $\mathrm{D}_{10}$ values. (Method 2 of ISO 11137, 1995 does not of course require any previous knowledge of typical product bioburden). Whichever practices are adopted for 
ensuring a low initial bioburden and the subsequent dose setting methods, the sterilisation process concludes with the irradiation of the product contained within a sealed package made from an appropriate, radiation resistant polymeric material. It is this terminal sterilisation aspect which provides both a practical and safe approach to achieving and maintaining extremely low SAL values.

\section{Compliance with ethical standards}

Conflict of interest The author declares that he has no conflict of interest.

Open Access This article is distributed under the terms of the Creative Commons Attribution 4.0 International License (http:// creativecommons.org/licenses/by/4.0/), which permits unrestricted use, distribution, and reproduction in any medium, provided you give appropriate credit to the original author(s) and the source, provide a link to the Creative Commons license, and indicate if changes were made.

\section{References}

Akeel A, Sibanda S, Martin SW, Paterson AWJ, Parsons BJ (2013) Chlorination and oxidation of heparin and hyaluronan by hypochlorous acid and hypochlorite anions: effect of sulfate groups on reaction pathways and kinetics. Free Radic Biol Med 56:72-88

Al-Assaf S, Navaratnam S, Parsons BJ, Phillips GO (2003) Chain scission of hyaluronan by peroxynitrite. Arch Biochem Biophys 411:73-82

Al-Assaf S, Navaratnam S, Parsons BJ, Phillips GO (2006) Chain scission of hyaluronan by carbonate and dichloride radical anions: potential reactive species in inflammation? Free Radic Biol Med 40:2018-2027

Amareld RW Jr, Wersocki M, Drohan M, Drohan WN, Burgess WH, Mann DM, Forng R-Y (2003) Controlled gammairradiation mediated pathogen inactivation of human urokinase preparations with significant recovery of enzymatic activity. Biologicals 31:261-264

American Association of Medical Instruments (AAMI) (2001) Sterilization of health care products-radiation sterilization-substantiation of $25 \mathrm{kGy}$ as a sterilization dose. In: AAMI TIR 27. Arlington, VA

Audette-Stuart M, Houee-Levin C, Potier M (2005) Radiationinduced protein fragmentation and inactivation in liquid and solid aqueous solutions. Role of $\mathrm{OH}$ and electrons. Radiat Phys Chem 72:301-306

Balazs EA, Davies JV, Phillips GO, Scheufele DS (1968) Polyanions and their complexes. Part III. Reactions of heparin, hyaluronic acid, sodium poly(ethylenesulphonate), sodium poly(styrenesulphonate) and sodium carboxymethylcellulose with hydroxyl radicals and hydrated electrons. J Chem Soc Perkin Trans 12:1420-1423
Bielski BHJ, Cabelli DE, Arudi RL (1985) Reactivity of $\mathrm{HO}_{2} / \mathrm{O}_{2}{ }^{-}$ radicals in aqueous solution. J Phys Chem 14:1041-1100

Camenisch TD, Spicer AP, Brehm-Gibson T, Biesterfeldt J, Augustine ML, Calabro A Jr et al (2000) Disruption of hyaluronan synthase-2 abrogates normal cardiac morphogenesis and hyaluronan-mediated transformation of epithelium to mesenchyme. J Clin Investig 106:349-360

Eriksen TE, Lind J, Merenyi G (1985) On the acid-base equilibrium of the carbonate radical. Radiat Phys Chem 26:197-199

Grieb T, Forng RY, Brown R, Owolabi T, Maddox E, McBain A, Drohan WN, Mann DM, Burgess WH (2002) Effective use of gamma radiation for pathogen inactivation of monoclonal antibody preparations. Biologicals 30: 207-216

Hardingham TE, Muir H (1972) The specific interaction of hyaluronic acid with cartilage proteoglycans. Biochim Biophys Acta 279:401-405

Hawkins CL, Rees MD, Davies MJ (2002) Superoxide radicals can act synergistically with hyochlorite to induce damage to proteins. FEBS Lett 510:41-44

Hernigou P, Gras G, Marinello G, Dormant D (2000) Influence of irradiation on the risk of transmission of HIV in bone grafts obtained from appropriately screened donors and followed by radiation sterilization. Cell Tissue Bank 1:279-289

International Atomic Energy Agency (2004) Code of practice for the radiation sterilization of tissue allografts: requirements for validation and routine control. Project No. INT 6/052, Vienna

International Standard Organisation (ISO) (1995a) Sterilization of medical devices-microbiological methods-Part 1 : estimation of population of microorganisms on products. ISO11737-1, Geneva

International Standard Organisation (ISO) (1995b) Sterilisation of health care products-requirement for validation and routine control—radiation sterilization. ISO11137, Geneva

International Standard Organisation (ISO) (1996) Sterilisation of health care products—radiation sterilisation-substantiation of $25 \mathrm{kGy}$ as a sterilisation dose for small or infrequent product batches. ISO/TR13409, Geneva

International Standard Organisation (ISO) (2006a) Sterilisation of health care products-radiation-Part 1: requirements for development, validation and routine control of a sterilisation process for medical devices. ISO11137-1, Geneva

International Standard Organisation (ISO) (2006b) Sterilisation of health care products-radiation-Part 2: establishing the sterilisation dose. ISO11137-2, Geneva

International Standard Organisation (ISO) (2006c) Sterilisation of health care products-radiation-Part 3: guidance on dosimetric aspects. ISO11137-3, Geneva

Kempner ES (2001) Effects of high-energy electrons and gamma rays directly on protein molecules. J Pharm Sci 90:1637-1646

Krisch RE, Flick MB, Trumbore CN (1991) Radiation chemical mechanisms of single strand and double strand break formation in irradiated SV40 DNA. Radiat Res 126:251-259

Laurent TC, Fraser JR (1982) Hyaluronan. FASEB J 6:2397-2404 
Laurent TC, Laurent UB, Fraser JR (1996) The structure and function of hyaluronan: an overview. Immunol Cell Biol 74:A1-A7

Lowe ME, Kempner ES (1982) Radiation inactivation of the glycoprotein, invertase. J Biol Chem 257:12478-12480

Milner CM, Day AJ (2003) TSG-6: a multifunctional protein associated with inflammation. J Cell Sci 116:1863-1873

Misra S, Obeid LM, Hannun YA, Minamisawa S, Berger FG, Markwald RR et al (2008) Hyaluronan constitutively regulates activation of COX-2-mediated cell survival activity in intestinal epithelial and colon carcinoma cells. J Biol Chem 283:14335-14344

Myint P, Deeble DJ, Beaumont PC, Blake SM, Phillips GO (1987) The reactivity of various free radicals with hyaluronic acid: steady-state and pulse radiolysis studies. Biochim Biophys Acta 925:194-202

Parsons BJ (1994) Chemical aspects of free radical reactions in connective tissue. In: Rice-Evans CA, Burdon RH (eds) Free radical damage and its control. Elsevier, Amsterdam, pp 281-300

Parsons BJ, Schulte-Frohlinde D, von Sonntag C (1978) Reaction of $\mathrm{Br}_{3}^{2-}$ with 2-Deoxy-D-ribose. A preferred attack at C-1. Z Naturforsch 33b:666

Parsons BJ, Kairiyama E, Phillips GO (2005) The development of a code of practice for the radiation sterilisation of tissue allograft. In: Kennedy JF, Phillips GO, Williams PA (eds) Sterilisation of tissues using ionizing radiations. CRC Woodhead Publishing Ltd, Cambridge, pp 39-63

Parsons BJ, Sibanda S, Heyes DJ, Paterson AW (2013) Reaction of superoxide radicals with glycosaminoglycan chloramides: a kinetic study. Free Radic Biol Med 61:111-118

Pattison DI, Davies MJ, Asmus KD (2002) Absolute rate constants for the formation of nitrogen-centred radicals from chloramines and their reactions with antioxidants. J Chem Soc Perkin Trans 2:1461-1467

Pattison DI, O' Reilly RJ, Skaff O, Radom L, Anderson RF, Davies MJ (2011) One-electron reduction of N-chlorinated and $\mathrm{N}$-brominated species is a source of radicals and bromine atom formation. Chem Res Toxicol 24:371-382

Poskrebyshev GA, Huie RE, Neta P (2003) Radiolytic reactions of monochloramine in aqueous solutions. J Phys Chem 107:7423-7428

Rees MD, Davies MJ (2006) Heparan sulfate degradation via reductive homolysis of its $N$-chloro derivatives. J Am Chem Soc 128:3085-3097

Rees MD, Hawkins CL, Davies MJ (2003) Hypochlorite-mediated fragmentation of hyaluronan, chondroitin sulfates, and related $\mathrm{N}$-acetyl glycosamines: evidence for chloramide intermediates, free radical transfer reactions, and site-specifi c fragmentation. J Am Chem Soc 125(13719): 13733

Rees MD, Hawkins CL, Davies MJ (2004) Hypochlorite and superoxide radicals can act synergistically to induce fragmentation of hyaluronan and chondroitin sulphates. Biochem J 381:175-184

Rees MD, Kennett EC, Whitelock JM, Davies MJ (2008) Oxidative damage to extracellular matrix and its role in human pathologies. Free Radic Biol Med 44:1973-2001
Sibanda S, Akeel A, Martin SW, Paterson AWJ, Edge R, AlAssaf S, Parsons BJ (2013a) Efficiencies of fragmentation of glycosaminoglycan chloramides of the extracellular matrix by oxidizing and reducing radicals: potential sitespecific targets in inflammation? Free Radic Biol Med 65:280-290

Sibanda S, Parsons BJ, Houee-Levin C, Marignier JL, Paterson AW, Heyes DJ (2013b) One-electron oxidation and reduction of glycosaminoglycan chloramides: a kinetic study. Free Radic Biol Med 63:126-134

Stern R, Asari AA, Sugahara KN (2006) Hyaluronan fragments: an information-rich system. Eur J Cell Biol 85:699-715

Terryn H, Vanhelleputte JP, Maquille A, Tilquin B (2006) Chemical analysis of solid-state irradiated human insulin. Pharm Res 23:2141-2148

Terryn H, Maquille A, Houee-Levin C, Tilquin B (2007) Irradiation of human insulin in aqueous solution, first step towards radiosterilisation. Int J Pharm 343:4-11

Thorne RF, Legg JW, Isacke CM (2004) The role of the CD44 transmembrane and cytoplasmic domains in co-ordinating adhesive and signalling events. J Cell Sci 117:373-380

Toole BP (1982) Developmental role of hyaluronate. Connect Tissue Res 10:93-100

Toole BP (1990) Hyaluronan and its binding proteins. Curr Opin Cell Biol 2:839-844

Toole BP, Slomiany MG (2008) Hyaluronan: a constitutive regulator of chemoresistance and malignancy in cancer cells. Semin Cancer Biol 18:244-250

Tran H, Marlowe K, McKenney K, Petrosian G, Griko Y, Burgess WH, Drohan WN, Iboden MA, Kempf C, Boschetti N, Mann DM (2004) Functional integrity of intravenous immunoglobulin following irradiation with a virucidal dose of gamma radiation. Biologicals 32:94-104

Turley EA, Noble PW, Bourguignon LY (2002) Signaling properties of hyaluronan receptors. J Biol Chem 277:4589-4592

Von Sonntag C (1987) The chemical basis of radiation biology. Taylor \& Francis Ltd., London

Wedlock DJ, Phillips GO, Davies A, Gormally J, Wyn-Jones E (1983) Depolymerization of sodium hyaluronate during freeze drying. Int J Biol Macromol 5:186-188

Yusof N, Hassan A, Abd Radman F, Hamid SA (2007) Challenges in validating the sterilisation dose for processed human amniotic membranes. Radiat Phys Chem 76:17561759

Zbikowska HM, Nowak P, Wachowicz B (2006) Protein modification caused by a high doe of gamma radiation in cryosterilised plasma: protective effects of ascorbate. Free Radic Biol Med 40:536-542

Zbikowska HM, Nowak P, Wachowicz B (2007a) Haemostatic properties of human plasma subjected to a sterilizing dose of gamma irradiation in the presence of ascorbate. Blood Coagul Fibrinolysis 18:271-277

Zbikowska HM, Nowak P, Wachowicz B (2007b) The role of ascorbate and histidine in fibrinogen protection against changes following exposure to a sterilizing dose of $\gamma$-irradiation. Blood Coagul Fibrinolysis 18:669-676 